\title{
Protection of Group B Streptococcal Infection in a Maternal-Neonate Mouse Model
}

\author{
Takako ITO, Toyo HIRANO \& Morimasa YOSHIOKA \\ Department of Microbiology, Tokyo Women's Medical College
}

(Received: 6/April/1984)

(Accepted: 10/July/1984)

Key words: Group B streptococcci, Mouse model, Protection, Virulence

\section{Summary}

Seven strains of group B streptococcus (GBS) of various types were examined for their virulence in adult and neonates mice by intraperitoneal and intracerebral inoculations. The neonates mice were commonly more sensitive against the challenge than the adult mice. Pregnant mice were immunized with anti type Ia antiserum or heat-killed vaccine, and inoculated with GBS intravaginally before the parturition. The mean number of neonates per litter delivered from normal pregnants was 13.7, while that from GBS-inoculated control pregnants was 3.8 or less. Those values obtained from pre-immunized pregnants were intermediates. The neonates which delivered from actively or adoptively immunized pregnants showed significantly higher protectivity against challenge of homologous and heterologous type strains than those of neonates from normal pregnants. It is concluded that either active or adoptive maternal immunization in mice resulted the vertical protectivity against challenge of homologous and heterologous type (III) organisms.

\section{Introduction}

Group B streptococcus (GBS) has been recognized as the main etiological agent of serious neonatal diseases. Vaginal carriage of GBS is common among pregnant women, and their neonates are frequently contaminated with the organisms. There are many reports in which the anti-GBS human or rabbit antisera as well as the globulin fractions showed protective activity in adult mice1) 6). We have also previously described on the passive immunization in adult mice using the type specific rabbit antisera7). There are no reports on the protection test in neonatal animals, except for neonate rats and chicken embryo8)9). These reports demonstrated the protectivity of the animal itself. The present investigation was designed to examine the virulence of GBS in neonate, and the effects of the maternal immunization on the indirect protectivity against group B streptococcal infection in their neonate mice.

\section{Materials and Methods}

Streptococcal strains. Prototype strains employed were O90 (type Ia), H36B (type Ib), V9 (type II) and M216 (type III) (from the Culture Collection of the Institute of Medical Science, University of Tokyo), and A909 (type Ic, from Dr. Maekawa, Sapporo Medical School). Also, clunical isolates of 59 (type Ia) and Yagura (type III) from the patients without and with group B streptococcal disease, respectively, were obtained from Dr. Iimura, Metropolitan Toshima Hospital. These strains were passaged in mice a few times by the method of Lancefield et al.1) Bacterial cultures in Todd-Hewitt broth (THB) were frozen in $1 \mathrm{ml}$ portions until use.

The strain 59 is used for preparation of vaccine: $0.3 \%$ formalinized vaccine used for antisera preparation

Address requests for reprints to Dr. Takako ITO, Department Microbiology, Tokyo Women's Medical College, 10 Kawada-cho, Shinjuku-ku, Tokyo, 162 Japan. 
in rabbits and heat-killed cell $\left(60^{\circ} \mathrm{C}, 30 \mathrm{~min}\right)$ vaccine used for adoptive immunization of mice.

Virulence test. The ddY line of conventional, closed colony mice were used. Four weeks old mice were obtained from the Sankyo Breeding Lab., Inc., Shizuoka. Neonate mice were propagated within a week after birth in our laboratory by mating the parturition mice. A $10 \mathrm{ml}$ volume of THB was inoculated with test organisms and incubated at $37^{\circ} \mathrm{C}$. The culture was ten-fold diluted up to $10^{-7}$ with THB, and spread on horse blood agar plates. Number of CFU per $\mathrm{ml}$ of the culture was counted. Appropriate dilutions of the culture were injected into a group of five mice, the amounts being 0.025 and $0.3 \mathrm{ml}$ for intraperitoneal (IP) or $0.01 \mathrm{ml}$ for intracerebral (IC) administration. Neonates were injected with the same amount of THB, and found to be intact. The $\mathrm{LD}_{50}$ was calculated from number of survivors on day 5 by the method of Behrens-Kärber.

Preparation of antisera. Male New Zealand white rabbits (Sankyo) weighing approximately $2 \mathrm{~kg}$ were immunized with formalinized vaccine of strain 59 by the method of Lancefield et al.1) The mixed GBS antiserum prepared with strain SS615 (type Ia) and clinical isolate, strain Ozawa (type III), was obtained from Dr. Nakagawa (Kitasato Institute, Tokyo). The antisera were stored at $-70^{\circ} \mathrm{C}$ until use.

Delivered neonate number from GBS colonized pregnants. A group of pregnant mice was passively immunized with $0.1 \mathrm{ml}$ of $1: 10$ diluted antiserum by intravaneous (IV) route approximately 4 days before the expected date of parturition. The second group of pregnant mice was immunized with heat-killed 59 vaccine 3 times at the interval of 3 days. The strain $59\left(4.9 \times 10^{7} \mathrm{CFU}\right)$ or the strain M216 $\left(2.4 \times 10^{7} \mathrm{CFU}\right)$ cells were inoculated intravaginally (IVg) in passively immunized, vaccinated and non-immunized mice, respectively, approximately 3 days before the expected date of parturition. Mean numbers of survived litter were calculated $24 \mathrm{hrs}$ after the parturition.

Protection tests of neonate from immunized pregnants. The one to two day-old neonates that were delivered from passively immnuized, vaccinated or non-immunized pregnant mice were inoculated by IP route with appropriate dilution $0.025 \mathrm{ml}$ of 59 or M216 cultures. The survivors were counted 5 days postinfection, when specimens from oral cavity and heart blood of all neonates, either dead or alive, were examined for streptococcal recovery on NO agar (see Table 2 footnote) ${ }^{10}$ ).

Preparation of test sera. Serum samples were obtained from maternal mice at the termination of experiments, and those of each immunized group were pooled. They were sterillized through the Millipore filter with $0.45 \mu \mathrm{m}$ pore and kept at $-70^{\circ} \mathrm{C}$ until the agglutination and the bactericidal tests.

Agglutination test. A series of 2 -fold dilutions of serum specimens were prepared with phosphate buffered saline ( $\mathrm{pH} 7.2$ ). One-half milliliter of diluates were added to $0.5 \mathrm{ml}$ of each the 59 or the M216 heatkilled cell suspension. After incubation at $37^{\circ} \mathrm{C}$ for $2 \mathrm{hrs}$ and at $4^{\circ} \mathrm{C}$ overnight, the agglutinin titers were read.

Bactericidal test. The assay was performed by a modification of the method of Stewardson-Krieger et al.2) Silicon coated tubes were filled with $1.0 \mathrm{ml}$ of the following mixture: $0.2 \mathrm{ml}$ of polymorphonuclear leukocytes, obtained by sedimentation of whole human blood supplemented with sodium citrated with the addition of $33.4 \%$ conrey 400 (dai-ichi Seiyaku Co.) and 9\% Ficoll (Sigma Chemical Co.), $0.2 \mathrm{ml}$ of test serum, $0.1 \mathrm{ml}$ of strain 59 or M216 cell suspension and $0.5 \mathrm{ml}$ of diluent, Eagle's minimal essential medium (Nissui Seiyaku Co.). Serum-, polymorphonuclear leukocyte- or both-deplaced controls were also prepared. At the begining and after $90 \mathrm{~min}$ of incubation at $37^{\circ} \mathrm{C}$ with end-over-end rotation, the mixtures diluted 10 -fold were inoculated onto blood agar plates. The bactericidal index (BI) was calculated by the following formula:

[1-(number of CFU at $90 \mathrm{~min} /$ number of $\mathrm{CFU}$ at zero-time) $] \times 100$.

Statistically analysis. The chi-square test was used to determine the significance of differences. The Yates correction was used when numbers were small in any of the subgroups. Probability level of $\mathrm{p}<0.05$ were considered significant.

\section{Results}

Lethal dose of GBS in mice of difference ages and routes. Results are shown in the Figure 1. Four type I 
Figure 1. Relation of $\mathrm{LD}_{50}$ of strains to mouse age and administration route.

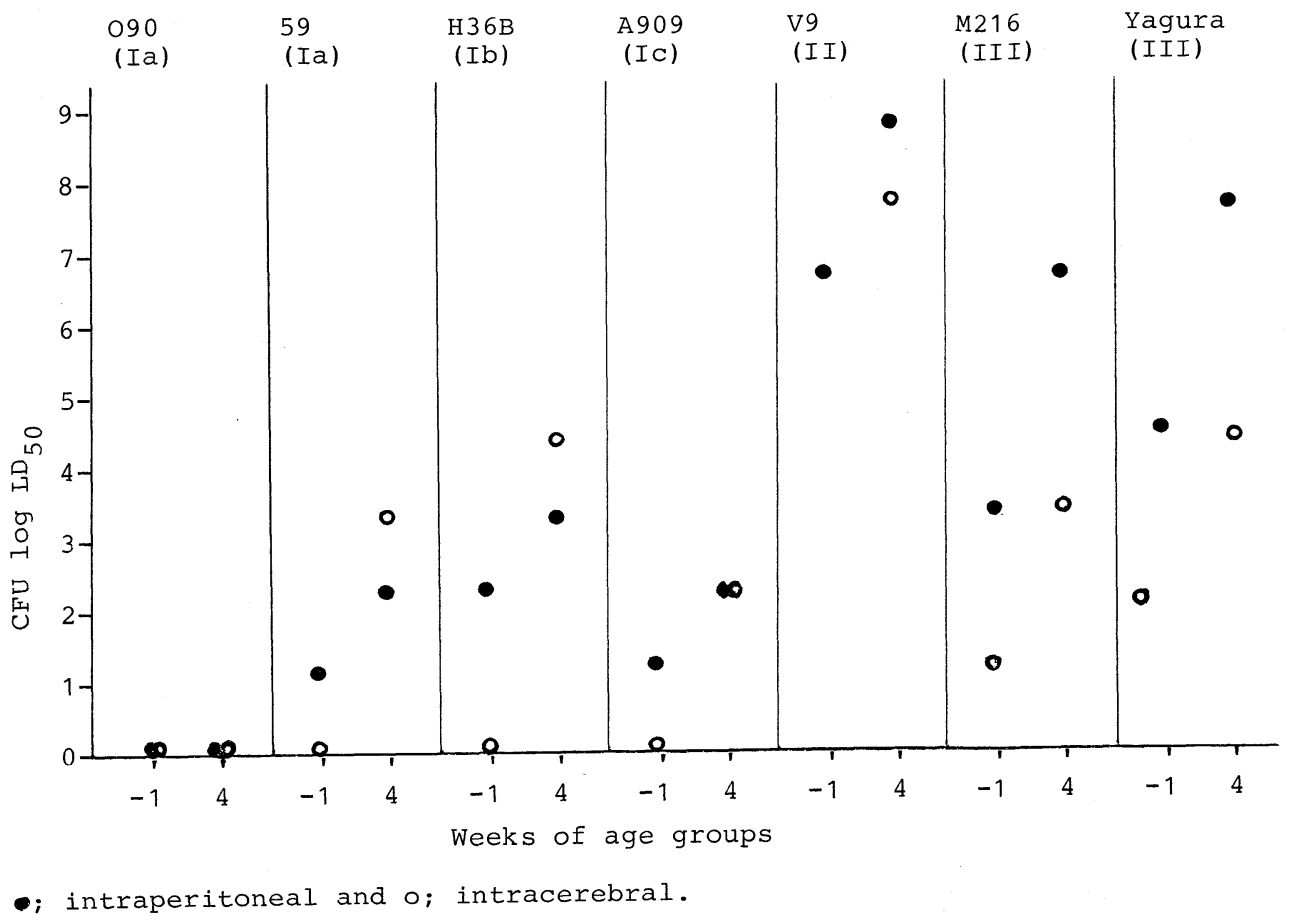

Table 1. Alive neonates delivered from GBS-inoculated pregnants.

\begin{tabular}{|c|c|c|c|c|}
\hline \multirow{3}{*}{ Immunized to pregnants } & \multicolumn{4}{|c|}{ Strains inoculated $\# 1$} \\
\hline & \multicolumn{2}{|c|}{59 (Ia) } & \multicolumn{2}{|c|}{ M216 (III) } \\
\hline & $\begin{array}{l}\text { Neonate no./ } \\
\text { pregnant no. }\end{array}$ & Mean litter & $\begin{array}{l}\text { Neonate no./ } \\
\text { pregnant no. }\end{array}$ & Mean litter \\
\hline $\begin{array}{l}\text { Mixed anti GBS serum* } \\
\text { (IV. IVg--birth) }\end{array}$ & $172 / 15$ & 11.5 & $43 / 8$ & 5.4 \\
\hline $\begin{array}{l}\text { Anti } 59 \text { serum* } \\
\text { (IV. IVg--birth) }\end{array}$ & $36 / 4$ & 9.0 & $12 / 4$ & $3.2^{\# 2}$ \\
\hline $\begin{array}{l}59 \text { vaccine }{ }^{* *} \\
\text { (IV -.-IV -..IV -..IVg - - birth) }\end{array}$ & $109 / 12$ & 9.1 & $31 / 5$ & 6.2 \\
\hline $\begin{array}{l}\text { Control*** } \\
\text { (IVg--birth) }\end{array}$ & $87 / 23$ & 3.8 & $11 / 7$ & 1.6 \\
\hline Normal delivery & & $192 / 14$ & 13.7 & \\
\hline
\end{tabular}

\#1 The $4.9 \times 10^{7} \mathrm{CFU}$ of 59 or the $2.4 \times 10^{7} \mathrm{CFU}$ of M216 culture of $0.05 \mathrm{ml}$ were inoculated IVg of pregnant mice respectively 3 days before the expected date of parturition.

\#2 $\mathrm{P}<0.25$. All of other data are significantly higher than that of challenge control.

* The passive immunization (IV) was performed with $0.1 \mathrm{ml}$ of $1: 10$ diluted antiserum. The parenthsis is schedule of treatment, and one day is -.

** The vaccine (IV) was performed with $0.1 \mathrm{ml}$ of $2.4 \times 10^{8}$ heat-killed 59 cells 3 times every 3 days.

***No immunization as control.

strains were considerably virulent to both age groups, and other type strains were moderate to low virulent. The neonate mice were commonly more sensitive than the adult mice, especially to type III infection, in which differences were $10^{3}$ to $10^{4}$ orders. Virulence by IC route were commonly higher than those of IP route, especially in type III infection. The strain 59 and M216 were used for the following experiments. 
Table 2. Isolation of GBS from alive neonates delivered from inoculated pregnants.

\begin{tabular}{lcccr}
\hline \multirow{2}{*}{ Immunized to pregnants } & \multicolumn{2}{c}{ Oral cavity } & \multicolumn{3}{c}{ Heart blood } \\
\cline { 2 - 5 } & Positive/tested & $\%$ & Positive/tested & $\%$ \\
\hline Mixed anti GBS serum* & $44 / 143$ & 32.8 & $8 / 172$ & 4.7 \\
59 vaccine** & $44 / 109$ & 40.4 & $6 / 109$ & 5.5 \\
Control*** $^{*}$ & $46 / 82$ & 56.1 & $16 / 82$ & 19.5 \\
\hline
\end{tabular}

\# Specimens from sacrificed neonates were spread on NO agar, which was performed with Heart Infusion agar containing the $0.3 \%$ yeast extract, the $0.001 \%$ colimycin, the $0.0015 \%$ nalidixic acid, the $0.0001 \%$ crystal violet and the $5 \%$ horse blood.

On astrisks, see the legend of table 1.

Table 3. Protectivity against GBS inoculation of neonates delivered from immunized pregnants.

\begin{tabular}{lcccc}
\hline \multirow{2}{*}{ Immunized to pregnants } & \multicolumn{3}{c}{ Strains inoculated $^{\#}$} \\
& \multicolumn{2}{c}{59 (Ia) } & \multicolumn{2}{c}{ M216 (III) } \\
\cline { 2 - 5 } & $\begin{array}{l}\text { Survivors } \\
\text { /tested }\end{array}$ & $\begin{array}{c}\% \\
\text { Protection }\end{array}$ & $\begin{array}{c}\text { Survivors } \\
\text { /tested }\end{array}$ & $\begin{array}{c}\% \\
\text { Protection }\end{array}$ \\
\hline Mixed anti GBS serum* & $65 / 85$ & 76.5 & $28 / 50$ & 56.0 \\
Anti 59 serum* & $40 / 42$ & 95.2 & $32 / 39$ & 82.1 \\
59 vaccine** & $79 / 88$ & 89.8 & $6 / 34$ & 17.6 \\
Control** $^{* *}$ & $26 / 80$ & 32.5 & $0 / 26$ & 0 \\
\hline
\end{tabular}

\# Neonates were injected IP with $87 \mathrm{CFU}\left(2.6 \mathrm{LD}_{50}\right)$ of 59 or $1.1 \times 10^{4} \mathrm{CFU}\left(3.3 \mathrm{LD}_{50}\right)$ of M216.

Survivors were counted 5 days after inoculation.

On astrisks, see the legend of table 1.

Table 4. Serum antibody titer puerperal mice immunized before delivery.

\begin{tabular}{|c|c|c|c|c|}
\hline \multirow[t]{2}{*}{ Sera } & \multicolumn{2}{|c|}{$\begin{array}{c}\text { Agglutination titer }(1:) \\
\text { Antigen }\end{array}$} & \multicolumn{2}{|c|}{$\begin{array}{c}\text { Bactericidal titer(BI) } \\
\text { Antigen }\end{array}$} \\
\hline & 59 (Ia) & M216 (III) & 59 (Ia) & M216 (III) \\
\hline $\begin{array}{l}\text { Maternal sera immunized with\# } \\
\text { Mixed anti GBS serum* }\end{array}$ & 32 & 64 & 83.7 & 96.9 \\
\hline Anti 59 serum* & 128 & 64 & 92.6 & 89.5 \\
\hline 59 vaccine v** $^{* *}$ & 512 & 128 & 84.9 & 93.2 \\
\hline Control*** & 2 & 2 & - & 11.6 \\
\hline Mixed anti GBS rabbit serum & 80 & 160 & 91.9 & 86.6 \\
\hline Anti 59 rabbit serum & 2560 & 640 & 83.2 & 88.9 \\
\hline
\end{tabular}

\# Pooled sera of maternal mice exanguinated at the completion of experiments were tested. On astrisks, see the legend of table 1.

Alive neonates delivered from GBS preexposed pregnants. As seen Table 1, mean number of neonates per litter delivered from normal pregnants was 13.7, while those from infected pregnants were 3.8 or less. Those values obtained from pre-immnuized pregnants were significantly above the latter ones except for the group pretreated with anti 59 serum and then challenged with M216. Recoveries of GBS from the oral cavity and the heart blood of survived neonates are shown in Table 2 , and positive rates are significantly lower in neonates delivered from the imnunized pregnants than those from non-pretreated pregnants.

Protectivity of neonates delivered from immunized pregnants. Since the vertical immunization lowered the vertical infection, protectivity of the neonates delivered from immunized pregnantes against direct GBS 
inoculation was examined (Table 3). Either the passively immnuized or the vaccinated group showed significantly higher protection against both challenge than the controls.

Serum antibody titers of peurperal immunized mice. As shown in Table 4, both of agglutinin and bactericidal antibody titers were not significantly different in any immunized groups.

\section{Discussion}

In this study, the virulence of GBS strains in both adult and neonate mice were high to moderate in type Ia, Ib and Ic, like as previously reports ${ }^{711112}$, and markedly low in type II like the data of Ferrieri et al. ${ }^{13)}$ The virulence of strain M216 used as a test organism in this study was also like other type III strains reported ${ }^{3) 1112}$ ). Comparing the sensitivity of animal ages, the neonates were commonly sensitive than the adult in mice, and also in rats, using type Ia ${ }^{14)}$ and type III13). The marked difference of sensitivity to neonate of type III in this study are suggesting that the higher adhesion of type III GBS to neonatal epitherial cells than to adults as indicated by Broughton and Baker15). In administration route, type III strains showed higher virulence in IC route than in IP route at both ages. This difference is in accord with the fact that the type III is frequently caused meningitis and suggests that type III GBS might have a tropism to nurvous system.

We observed that GBS in the birth canal of normal pregnent mice was colonized for 5 days after inoculation IVg, and disappeared in following 1 to 2 weeks. When carrying the GBS at the time of parturition, pregnants and their babies have high risk of GBS infection. A part of pregnants fell in septicemia or died during the parturition. Most neonates delivered from such pregnants died of septicemia within $24 \mathrm{hrs}$ after birth, even survived neonates carried GBS in oral cavity and in heart blood. The active and adoptive immunization to pregnant mice significantly decreased the risk of infection to both the mother and her babies at the parturition. The litter size from immunized pregnants was significantly higher than those from not immunized.

The protective activity of the maternal serum should persist for certain period of time after passive immunization, because sera bled from the mother a week after the parturition showed still high agglutinin titer. We injected the antiserum $24 \mathrm{hrs}$ before the challenge, however, the effective time interval of the antiserum injection and the challenge varied from $2.5 \mathrm{hrs}$ to a few monthes by the investigators ${ }^{4) 59)}$ Both of the mixed and strain 59 antisera used for the passive immnuization showed protective potencies. Although the agglutinin titers of the serum from 59 vaccinated mice were higher than those of the other mice, bactericidal titers to 59 and M216 cells were not significantly different. These agglutinin titers would be received with effect of the group specific polysaccharide because formalinized whole bacteria were used to preparation for rabbit antisera. However the group specific polysaccharide are not protective. Therefore, the agglutinin titers in study would not be correctly parallel with protectivity against mice.

The immunization with type Ia antiserum and vaccine to pregnants effectively protected neonates they delivered against type Ia as well as type III challenge. The cross-protectivity of type III of anti-type Ia antibody is reported by Baltimore et $\mathrm{al}^{3{ }^{316} \text { ) }}$ in mice model and by Tieffenberg et $\mathrm{al}^{17}$ ) in chicken model. Their reports did not clear whether the type Ia specific antigen itself has the dross-protectivity against the type III challenge. Another antigens, in addition to the type specific antigens were reported previously16). One of them is the Ibc protein antigen which is present at each types except to Ia, and they have protectivity. Other is the Iabc minor common carbohydrate antigen which is present at all I types, and they also have protectivity. Therefore, the cross-protection in this study could be due to the presence of another certain antibody produced in the mother mouse. The hypothesis would be supported by facts that the type Ia specific opsonic antibody passes the placenta ${ }^{18}$ ) and that the type III agglutinin does not pass ${ }^{19}$. The unknown antibody also would be passed through the placentas.

We have shown that the maternal type Ia GBS immunization either actively or adoptively was effective to protect mice from the vertical type Ia infection. Furthermore, such an immunization would give rise to 
cross-protection against type III infection.

\section{References}

1) Lancefield, R.C., McCarty, M. \& Everly, W.M.: Multiple mouse-protection antibodies directed against group B streptococci: special reference to antibodies effective against protection antigens. J. Exp. Med., 142: 165-179, 1975.

2) Stewardson-Krieger, P.B., Albrandt, K., Nevin, T., Kretschmer, R.R. \& Gotoff, S.P.: Perinatal immunity to group B $\beta$ hemolytic streptococcus type Ia. J. Infect. Dis., 136: 649-654, 1977.

3) Baltimore, R.S., Kasper, D.L. \& Veccitto, J.: Mouse protection test for group B streptococcus type III. J. Infect. Dis., 140: 81-88, 1979.

4) Cleat, P.H. \& Coid, C.R.: Protection of mice against group B streptococcus type Ia by IgG components of a rabbit antisera. Med. Microbiol. Immunol., 169: 9-14, 1980.

5) Stanton, B.F., Baltimore, R.S. \& Shedd, D.G.: Effects on routes and time of administration of antiserum on protection of mice from lethal infection due to group B streptococcus type III. Infect. immun., 31: 391-395, 1981.

6) Fleming, D.O.: Mouse protection assay for group B streptococcus type III. Infect. Immun., 35: 240-247, 1982.

7) Hirano, T.: Experimental group B streptococcal infection and immunization in mice. J. Tokyo Women's Med. College, 52: 1406-1416, 1982.

8) Santos, J.I., Shigeoka, A.O., Rote, N.S. \& Hill, H.R.: Protective effeciency of a modified immune serum globulin in experimental group B streptococcal infection. J. Pediatr., 99: 873-879, 1981.

9) Vogel, L.C., Kretschmer, R.R., Padnos, D.M., Kelly, P.D. \& Gotoff, S.P.: Protective value of gamma globulin preparations against group B streptococcal in chicken embryos and mice. Pediatr. Res., 14: 788-792, 1980.

10) Nakajima, K., Okuyama, M., Tamura, T.\& Okuda, K.: Studies on a new selective medium for the isolation of group A, B, C and G hemolytic streptococci. Jap. Assoc. Infect. Dis., 55: 501-510, 1981.

11) Wennerstrom, D.E. \& Schutt, R.W.: Adult mice as a model for early onset group B streptococcal disease. Infect. Immun., 19: 741-744, 1978.

12) Fleming, D.O.: Mucin model for group B type III streptococcal infection in mice. Infect. Immun., 27: 499-454, 1980.

13) Ferrieri, P., Burke, B. \& Nelson, J.: Production of bacteremia and meningitis infant rats with group B streptococcal serotypes. Infect. Immun., 27: 1023-1032, 1980.

14) Schuit, K.E. \& DeBiasco, R.: Kinetics of phagocyte response to group B streptococcal infections in newborn rats. Infect. immun., 28: 319-324, 1980.

15) Broughton, R.A. \& Baker, C.J.: Role of adherence in the phagocytosis of neonatal group B streptococcal infection. Infect. Immun., 39: 837-843, 1983.

16) Baltimore, R.S., Kasper, D.L., Baker, C.J. \& Goroff, D.K.: Antigenic specificity of opsonophagocytic antibodies in rabbit anti-sera to group B streptococci. J. Immunol., 118: 673-678, 1977.

17) Tieffenberg, J., Vogel, L., Kretschmer, R.R., Padnos, D. \& Gotoff, S.P.: Chicken embryo model for type III group B beta-hemolytic streptococcal septicemia. Infect. Immun., 19: 481-485, 1978.

18) Mathews, J.H., Klesius, P.H. \& Zimmerman, R.A.: Opsonin system of the group B streptococcus. Infect. immun., 19: 1315-1320, 1974.

19) Kelsius, P.H., Zimmerman, R.A., Mathews, J.H. \& Krushak, D.H.: Cellular and humoral immune response to group B streptococci. J. Pediatr., 83: 926-932, 1973. 


\section{母仔免疫マウスモデルに打ける B 群レンサ球菌感染防御}

東京女子医科大学微生物学教室

伊藤 隆子 平野

(昭和59年 4 月 6 日受付)

(昭和 59 年 7 月 10 日受理)

B 群レンサ球菌（GBS）各血清型計 7 株につい て, ddY マウスを用いビルレンスを調べた結果， 新生仔（1 週齢以内）はアダルト（4 週齢以上） より, 脳内接種は腹腔内接種より (特に III 型) 高 い感受性を示した。

出生後生存仔数は, 正常母 13.7 匹に対し臸内 Ia 型株接種母では3.8匹と少く,死仔はすべて敗血症 死で, GBS 産道内保有は新生仔敗血症罹患の高い

別刷請求先：（テ162）新宿区市谷河田町 10 番地 東京女子医科大学微生物学教室
危険性を示した。それに対し受働(ウサギ抗血清) および自働 (Ia 型加熱死菌ワクチン) 免疫処理母 では各々 $11.5 ， 9.0$ 匹と中間の值を示した。

新生仔への腹腔内攻撃実験では，正常母からの 新生仔では防御率 $32.5 \%$ と低いのに対し, 免疫処 理母からの新生仔では76.5-95.2\%と高かった。 また抗 Ia 型血清投与母からの新生仔への III 型 株攻撃に対しても $82.1 \%$ の防御率を示した.

各実験群母の血清抗体価は, 凝集素価, 殺菌抗 体価ともに, 免疫処理群の方が有意の值を示した. 